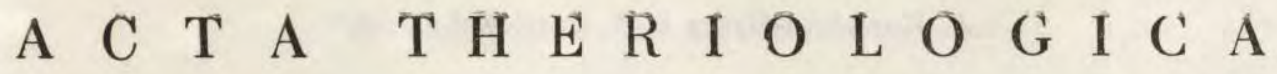 \\ VOL. XIV, 32: 433-478 \\ BIAŁOWIEŻA \\ 15.XII.1969
}

\author{
Alina KOW A L S A - DYR C Z \\ \& Aurelia PAWŁOWSKA - INDYK
}

\section{The Male Accessory Reproductive Organs in the Striped Field Mouse}

[With Plates XVIII-XXI]

\begin{abstract}
Microscopic analysis of genital system in 5 sexually mature males of A. agrarius and 26 embryos at different stages of the development has allowed to state that secretory function is performed by the following structures: cauda epididymidis, vas deferens, gl. ampullarum et ampulla, vesiculae seminales, gl. coagulantes, gl. prostaticae, gl. bulbo-urethrales, gl. urethrales and gl. praeputiales. Localization, structure and development of those organs in $A$. agrarius are more or less the same as in other Muridae. Prostatic gland in the investigated species is differentiated into three different groups termed: dorsal, lateral and ventral prostate; the structure of this latter being distinctly different. It seems that in Muridae the separate groups of the prostate are physiologically not homologous to those present in Microtidae.
\end{abstract}

\section{INTRODUCTION}

The structure and development of male genital organs in Muridae have been the subject of many investigations (R a uther, 1904; Rietsche1, 1929; Szarski, 1935; R a y a ud, 1942; Kratochví1, 1960; Arata, 1964). In most papers the investigations involve the genera Mus and Rattus; so far, however, neither microscopic structure nor the development of the accessory glands in the representatives of the genus Apodemus have been elaborated. The present paper gives the description of the structure and development of the male accessory glands in Apodemus agrarius ( $\mathrm{Pa} 11 \mathrm{as}, 1771)$.

\section{MATERIAL AND METHODS}

Sexually mature, adult males, as well as pregnant females were caught in Wrocław and in the environment of Milicz. Material used for investigations consisted of genital organs taken from 5 sexually mature males and 29 embryos coming from different litters. The body length being measured the embryos were divided into 4 groups according to the stage of their development, namely: stage I $-4 \mathrm{em}-$ bryos about $11 \mathrm{~mm}$ long (coming from one litter); stage II -2 embryos about 
$14.5 \mathrm{~mm}$ long (from one litter); stage III - 20 embryos about $18 \mathrm{~mm}$ long (from 6 different litters); stage IV -3 embryos about $25 \mathrm{~mm}$ long (from one litter).

The whole material was fixed in Bouin fluid. The urogenital complexes of adult males and caudal parts of embryos were sectioned serially in the transverse and sagittal planes at $4-7 \mu$ thickness. They were stained with Delafield hematoxylin and eosin.

III. MACROSCOPIC AND MICROSCOPIC STRUCTURE OF THE ACCESSORY GLANDS IN THE SEXUALLY MATURE MALE

Of the male genital organs the following structures reveal excretory activity: cauda epididymidis, vas deferens, gl. ampullarum and the ampulla, vesiculae seminales, gl. coagulantes, gl. prostaticae, gl. bulbo-urethrales and gl. praeputiales.

The cauda epididymidis adheres the posterior margin of the testicle. It is a large (measuring one half of length of the testicle), baggy structure, furrowed with numerous folds of the epididymidis canal (Fig. 1, 2 , ce). A thin vas deferens originating from the epididymis becomes progressively thickened while approaching the urethra. Its terminal portion is widened forming the ampulla. Dorsally to the urinary bladder there is a pair of seminal vesicles (Figs. 1, 2, vs). They have shape of broad, dorso-ventrally flattened cylinders, centripetally curved on their distal ends. The tubes of the coagulating glands (Figs. 1, 2, gc) are attached to the lesser curvatures of the vesicular gland, and partially to their lateral surfaces. The bases of the vesicles are surrounded from their ventrall side by the free ampullary tubes (Fig. 1, am). Cranial portion of the urethra, below the neck of the urinary bladder, is surrounded by numerous lobes of prostatic glands - the dorsal prostate (Fig. 2, pd) which on its both sides passes into lateral prostatic lobes (Fig. 1, pl) continuing along the lateral surfaces of the urethra. The latters are caudally connected with two ventral prostatic lobes (Fig. 2, pv). These are not distinct morphologically and lie under the urinary bladder on the ventral surface of the urethra. A pair of small pear-shaped bulbo-urethral glands (Fig. 2, gb) adheres the dorsal surface of the bulbus penis.

Within the cauda epididymidis one may distinguish 2 regions (Fig. 3): (1) defined by the ductus epididymidis includes the proximal portion and the whole dorsal part of the cauda epididymidis, (2) defined by the vas deferens, includes the distal, ventral part of the cauda epididymidis. Both regions are separated by smooth muscle bands which appear also within the region 2. Within the first region the particular loops of the duct are separated only by the connective tissue. The cauda epididymidis - as a whole - is surrounded by a layer of smooth muscle, while the bands of the striated muscle cover it from outside. In both parts of 
the epididymis the epithelium is prismatic with long stereocilia; it shows secretory activity. Compact masses of the spermatozoa mixed with fine-grained secretion are present in the lumen of the ducts.

The vas deferens, after having left the cauda epididymidis, is thin (its diameter is about $740 \mu$ ). The prismatic epithelium of the duct equipped with stereocilia is secretory active. Here and there one observes some flattened basal cells. The diameter of the vas deferens gradually increases (about $1.2 \mathrm{~mm}$ ). The epithelium lining the lumen is thrown in folds more and more numerous and higher while the vas deferens approaches the urethra. In the terminal portion of the vas deferens one observes pockets with separate lumina (Fig. 4). The secretory processes in the epithelium of this terminal portion of the vas deferens are distinctly intensified (Fig. 7). The muscular membrane of the vas deferens consists of spiral fibres whose course: perpendicular in exterior parts and horizontal in the interior ones give the impression of two layers, while sectioned transversally.

The ampulla vasis deferentis and the gl. ampullarum. Distal end of each vas deferens is widened forming the ampulla vasis deferentis (Fig. 5 , a) whose walls are continuous with the walls of the vas deferens. The ampulla vasis deferentis is a glandular structure whose epithelium is thrown in numerous folds. Its interior is occupied by a large central cavity. The epithelium lining the lumen is prismatic, somewhat lower than that of the vas deferens, lacking the stereocilia. Apical surfaces of the epithelial cells filled with secretion are bulging toward the lumen. Secretion present within the ampulla is nubbly and stains intensly with eosin.

Numerous free tubes of the ampullary glands (Fig. 5, am) are present on the ventral and lateral sides of each ampulla. They are built of cubic epithelium and filled with a great amount of course-grained secretion staining violet with hematoxylin-eosin (Fig. 8). The free ampullar tubes open into the ampullae.

The vesiculae seminalis are conspicuous, lobulated organs. Their distal portion have a tubular structure. In central and proximal portions the inside of the vesicle is taken by the elongated cavity, the walls of which are formed by a strongly folded mucous membrane. From outside there is a layer of smooth muscle and connective tissue. The epithelium of the vesicles is cylindric with either spherical or oval nuclei, lying basally (Fig. 6). The cytoplasm of the apical parts of the cells is basophilous (it stains with hematoxylin) while the secretion filling tightly the lumen of the vesicle is eosinophilous, homogeneous and strongly refracting the light. In their terminal parts the ducts of seminal vesicles are most frequently (in 3 of 5 individuals) united with the vasa deferentia, there by 
forming very short ejaculatory duct which should be rather termed the ostium ejaculatorium. One individual had only the right ejaculatory duct, the left seminal veșicle duct and the left vas deferens opened to the urethra separately. Finally, one individual was completely lacking the ejaculatory ducts (Fig. 15, v, vs). This proves a great individual variability in this respect. In each case those ducts open to the dorsal, paired pockets of the urethra, within the colliculus seminalis (Fig. 15, k).

The glandulae coagulantes are built of very broad tubes filled with secretion staining pale-red with eosin. The separate tubes are surrounded with circular bands of smooth muscle, continuous with the muscular wall of the seminal vesicles. The epithelium of the tubes is cylindrical (lower than in the seminal vesicles) with large, spherical nuclei lying basally or in the lower part of the cell (Fig. 11). Here and there one observes some flattened basal cells. The mucous membrane of these glands is arranged in curved folds which project into the lumen. The secretion is of merocrine type. The glands drain through excretory ducts (one on each side) which have the form of wide tubes with folded walls. Both ducts (Figs. 15, 14, gc) are the first ones that enter laterally the crista urethralis and open to the urethra within the colliculus seminalis at the site where the lumen of the urethra is joined with the lumen of the dorsal pockets. It also happens that one of the ducts opens more cranially - to the pocket, while the second opens to the main lumen of the urethra.

The glandulae prostaticae dorsales adhere the dorsal wall of the urethra, reaching the basis of the seminal vesicles cranially, and the level of the ventral prostate - caudally. The tubes of the dorsal prostate join the tubes of the lateral prostate, so that there is no visible border between them. Cranially, the latter are even forcing among the tubes of the dorsal prostate and divide them into central and lateral groups. The tubes of the dorsal prostate are rather narrow. They are built of cylindrical (Fig. 10) or cubic epithelium (depending on the activity of the cell). The nuclei are situated basally, their shape is spherical or irregular. The cytoplasm is filled with eosinophilous grains. The secretion (apocrine in type) is homogenous, staining pink with eosin (a little more intensly than the secretion of the coagulating glands). The separate tubes are surrounded with circular bands of smooth muscle and with connective tissue. One also encounters numerous agglomerations of nervous tissue. The efferent ducts whose number is about 20 (Fig. 14, pd) enter the dorsal wall of the urethra cranially to the $m$. urethralis, and open on the apex of the dorsal pockets within the colliculus seminalis. Only most laterally situated ducts are opening to the urethra after its lumen is fused with the lumen of its pockets. 
The glandulae prostaticae laterales cranially surround the sides of the tubes of the dorsal prostate; more caudally they are situated along the lateral walls of the urethra, while their caudal portions adhere laterally the tubes of the ventral prostate. Although they are not distinctly separated from the tubes of the dorsal prostate, they nevertheless differ from them in their structure and kind of the discharged secretion.

The tubes of the lateral prostate are wider and regular, their mucous membrane is never thrown into folds projecting into their lumen. The epithelium is prismatic (Figs. 9, 12) with spherical nuclei weakly basophilous, lying at or near the base of the cell. The cytoplasm is eosinophilous with numerous grains. The apocrine secretion is discharged in form of fine grains. Secretion filling the tubes is floculent and coagulated; it never appears in great quantities. It stains with eosin less intensely than the secretion of the dorsal prostate. The efferent ducts (4-6 on each side of the gland) are situated between median and lateral ducts of the dorsal prostate (Fig. 14, pl). They enter the dorso-lateral wall of the urethra, cranially to $m$. urethralis which subsequently surrounds them together with other ducts and the urethra. Some of the lateral ducts are opening into the dorsal pockets while the others open into the urethra after its lumen is being fused with the lumen of the dorsal pockets.

Glandulae prostaticae ventrales are a group of prostatic tubes situated on ventral surface of the urethra. Considering their microscopic structure they are most distinctly separated. They course from the posterior end of the colliculus seminalis along a large portion of the pars membranceea urethrae. From the cranial, narrowed part of the gland are emering long efferent ducts which run in cranial direction, exteriorily to the $m$. urethralis (Fig. 15, pv). At the site where the $m$. urethralis is taking its origin they enter the wall of the urethra (Fig. 14, pv) and course caudally under this muscle. They finally open into the lumen of the urethra in its ventral wall, somewhat caudally to the colliculus seminalis. Such a considerable elongation of the ventral prostate ducts and the loops they are making may perhaps be explained by the fact that the $m$. urethralis whose differentiation takes place relatively late in the course of the development is expanding in anterior direction "stretches " the ducts and shifts them cranialward. The number of the ventral prostate ducts varies individually. So of 5 examined males one individual had 4 right and 2 left ducts, 2 specimens had 2 right and 3 left ducts, one had 3 right and 2 left ducts, finally, one male had 2 ducts on either side.

The tubes of the ventral prostate differ in size - from completely narrow ones up to wide with a large lumen. Each tube is surrounded with 
circular bands of smooth muscle; the space between the tubes is filled by loose connective tissue containing numerous blood vessels and nerves. Mucous membrane of the tubes forms, as a rule, the folds projecting into lumen (Fig. 12), that is why the lumen is never regular. The epithelium is columnar (the height of the cell is $4-6$ times greater than its width) with spherical or oval nuclei highly basophilous placed either in the lower part or in the middle of the cell (but never at its basis Figs. 12, 13). Cytoplasm of the lower part of the cells is highly basophilous, homogeneous, and surrounds the nucleus which is plunged in it. Above the nucleus the cytoplasm is light, eosinophilous with darker basophilous grains, while the cytoplasm of the apical pole of the cell is again highly basophilous, tightly filled with nubbles of the secretion. The secretion is apocrine. One encounters many binuclear cells. Flat basal cells wedged between columnar cells of the epithelium are observed here and there. The secretion filling the tubes is course-grained and basophilous (Fig. 13).

Glandulae urethrales. Single tubes of those glands appear cranially in ventral wall of the urethra on a level with the openings of the ventral prostate (within the colliculus seminalis they are absent). They are present within the entire pars membranacea urethrae being chiefly grouped in connective tissue of the ventral wall of the urethra (Fig. 18, gu). Within dorsal and lateral walls of the urethra one observes only single glandular tubes. The greatest agglomeration of the urethral glands is found in the wall of the sinus urethrae bulbi (Fig. 16, gu). They do not appear in the penile urethra. Numerous tubes of the urethral gland are found along the whole length of the ducts of the bulbo-urethral glands (Fig. 17, gu). They surround also the distal portion of the bulbo-urethral gland at the site where the efferent duct of the gland takes its origin.

The urethral glands are built of tubes which resemble vesicles because of their strongly contracted lumen. The epithelium of the tubes is prismatic, the cells have small, oval and highly basophilous nuclei situated at their bases, and highly eosinophilous, grainy cytoplasm. Each gland consisting of a few vesicle-like tubules has an efferent tube with a distinct lumen. It is built of a cubic epithelium, whose cells have feebly eosinophilous cytoplasm and big, spherical, feebly staining nuclei lying centrally. The efferent tubes open into the lumen of the urethra (Fig. 18). The secretion of the urethral glands is fine-grained or flakky, and feebly eosinophilous.

Glandulae bulbo-urethrales are small, pear-shaped glands situated on both sides of the intestine, posteriorly to the $m$. bulbo-cavernosus. Proximal portion of this gland is wedged between the $m$. bulbo-cavernosus and $m$. ischiocavernosus. On the outside the gland is surrounded by 
layer of striated muscle bands (they are absent on the paracentral surface of the gland) and smooth muscle and connective tissue layers lying below. These two last layers penetrate inside the gland dividing in into lobulae. It is a tubulo-alveolar gland. The glandular cells are high with small, basally situated nuclei and grainy, basophilous cytoplasm (Fig. 19). The inside of the gland is taken by irregular cavities. The ducts (one at each gland) leave the proximal end of the gland, enter between the $m$. bulbo-cavernosus and $m$. ischio-cavernosus, course within the dorsal wall of the urethra and open into the sinus urethrae bulbi. They are relatively short, built of a single layer of prismatic epithelium, surrounded by a cuff of the urethral glands, identical with those that appear within the bulbus penis. Within this glandular mass surrounding the ducts one observes the agglomerations of glandular tissue, identical with the tissue of the bulbo-urethral glands (Fig. 17, gb).

In adult males the structure of the glandulae praeputiales has not been investigated.

\section{EMBRYONIC DEVELOPMENT OF THE GL. ACCESSORIAE}

\section{Muillerian Ducts}

No traces of those structures are stated in sexually mature males. This fact is confirmed by a relatively quick regression of those ducts in the course of embryonic development.

In embryos about $11 \mathrm{~mm}$ long the Müllerian ducts are paired and continuous throughout their whole course. They possess a distinct lumen filled with eosinophilous secretion. The diameter of the ducts is somewhat smaller than the diameter of the Wolffian ducts, being distinctly widened only in their terminal portion, adhering the dorsal wall of the sinus (Fig. 20, M).

In embryos about $14.5 \mathrm{~mm}$ long the Müllerian ducts are still continuous. The interior walls of both ducts are adjoining within the funiculus genitalis, and somewhat farther caudally they fuse into one duct with a double lumen, lying between the Wolffian ducts. In distal portion there is already a single canal with a large lumen which is connected with the dorsal wall of the sinus urogenitalis. A string of cells originating from the sinus is jammed between the walls of this canal.

In embryos about $18 \mathrm{~mm}$ long cranial portions of the ducts are not continuous being here and there reduced to strings of cells without lumen. The form of a canal with a distinct lumen is maintained solely by the distal portion of the Müllerian duct adjoining the dorsal wall of the sinus (Fig. 22, M). 
In embryos about $25 \mathrm{~mm}$ long (immediately before birth) a structure defined as utriculus prostaticus adhering the dorsal wall of the sinus urogenitalis is the only remnant of the Müllerian ducts. It is a cranially blind canal appearing on the level with the buds of the coagulating glands. The distal, widened portion of the canal with a large lumen, is connected with two strings of cells, growing from the dorsal wall of the sinus. A small agglomeration of mesenchyme jammed between those strings gives this structure a characteristic appearance, similar to that encountered in all Rodentia. The utriculus prostaticus lies between the ejaculatory ducts (Figs. 26, 30, ut).

\section{Wolffian Ducts and Their Glands}

The diameter (about $51 \mu$ ) of Wolffian ducts (Fig. 20, W) surpasses that of Müllerian ducts in embryos merely about $11 \mathrm{~mm}$ long. The Wolffian ducts open into the urogenital sinus on lateral elevations of its dorsal wall. Terminal portions of the Wolffian ducts adhering the dorsal wall of the sinus are distinctly widened. This widening caused by the outside expansion of the lateral walls of the ducts constitutes the bud of the seminal vesicle (Fig. 21, vs).

In embryos about $14.5 \mathrm{~mm}$ long the buds of the seminal vesicles appear on either side in form of short tubes oriented dorsolaterally and at the same time - in anterior direction. Numerous mitoses are observed in cells lying within the buds.

In embryos about $18 \mathrm{~mm}$ long the diameter of the Wolffian ducts is only slightly larger (about $52 \mu$ ) if compared with the earlier stages. No significant changes in the structure of the seminal vesicle buds have been stated either.

In embryos immediately before birth, the average diameter of the Wolffian ducts amounts to $76 \mu$. The mesenchyme surrounding a single duct is distinctly condensed, its cellular elements being arranged concentrically around the duct (Figs. 23, 25). A similar but still more intense concentration of mesenchyme is observed around the tubes of the seminal vesicles (Fig. 25, vs). The size of the tubes increases remarkably in dorsal and cranial directions. Consequently the distal portions of the tubes are lying beyond the funiculus genitalis. In the latter portions of the buds the epithelium is thrown into folds, one also observes the development of secondary tubes (Fig. 23, vs). Tubular buds of the vesicles connected by their proximal parts with the Wolffian ducts open with them into the urethra by means of short ejaculatory ducts (Figs. 26 and 30 , de). 


\section{Glands Originating From the Epithelium of the Sinus Urogenitalis}

\subsection{Glandulae prostaticae and gl. coagulantes}

The listed below buds do not appear earlier than in embryos about $18 \mathrm{~mm}$ long:

(a) Gl. coagulantes - in form of a pair of elongated, solid cellular plugs, developing from the dorso-lateral walls of the sinus urogenitalis, cranially to the openings of the Wolffian ducts (Fig. 22, gc). Considering the state of their development they had to appear somewhat earlier than the prostatic buds.

(b) Gl. prostaticae ventrales - in form of solid epithelial buds developing from the ventral wall of the sinus, on the level with the coagulating glands or caudally to them. The number of those buds varies individually: 2 on the right and 1 on the left sides (in 2 specimens), 2 on the left and 1 on the right sides (in one specimen) and 1 pair of buds (in 4 specimens).

(c) Gl. prostaticae dorsales et laterales. They appear only in some embryos of this length in form of minute epithelial buds developing from the dorsal and lateral walls of the urogenital sinus, immediately behind the openings of the Wolffian ducts.

In embryos about $25 \mathrm{~mm}$ long:

(a) The buds of the coagulating glands grew remarkably longer being still lumenless. They continue laterally to the Wolffian ducts directed dorsally and cranially (Fig. 23, 27, gc).

(b) The buds of the gl. prostaticae ventrales have already grown beyond the differentiating $m$. urethralis and are oriented caudally (Figs. $26,29,30, \mathrm{pv})$. Their distal portions, still lumenless are surrounded by condensed, circularly arranged mesenchyme. This is true for the pair of cranial buds (Fig. 29, pv) lying the level with the buds of coagulating glands. The second pair of buds, the smaller ones, is situated on the level with the openings of the vasa deferentia into the sinus (2 pairs of buds have been stated in two individuals). One specimen had 2 buds on the right and 1 bud on the left side.

(c) The buds of the gl. prostaticae laterales situated on the level with posterior pair of the ventral prostate buds are growing from lateral walls of the sinus, in form of solid cellular plugs, $4-6$ on each side (Figs. 26, $30, \mathrm{pl})$.

The buds of the gl. prostaticae dorsales (5-10 on each side) are growing most caudally from the dorsal wall of the sinus behind the openings of the Wolffian ducts. They have the form of elongated cellular plugs without lumen (Fig. 28). 


\subsection{Gl. bulbo-urethrales}

The buds of those glands appear as early as in embryos about $11 \mathrm{~mm}$ long. They develop from lateral walls of the sinus urogenitalis at the site where the sinus forms a distinct widening - the beginning of the sinus urethrae bulbi. They are solid epithal buds directed dorsally, one on each side (Fig. 24).

In each bud of embryos about $18 \mathrm{~mm}$ long one may already distinguish a proximal, tubular portion (possessing lumen) of the future duct, and a distal, club-shaped lumenless portion which will give rise to the substance of the gland. Those latter lie within the blastema which had been formed earlier from the blastema of the bulbus penis.

In embryos about $25 \mathrm{~mm}$ long one observes a further differentiation of the buds. In club-shaped part one may distinguish the buds of future lobes of the gland in form of secondary epithelial buds possessing lumen (Fig. 34, gb). The buds are considerably elongated being directed dorsally and caudally.

It should be noticed that one individual had 2 buds of the gl. bulbourethrales on each side (Fig. 33), the second embryo had 2 buds on the left and 1 bud on the right sides, and the third specimen had one bud on either side.

\subsection{Glandulae urethrales}

First detectable buds of those glands appear in embryos about $25 \mathrm{~mm}$ long, situated more or less in the middle of the pelvic part of the sinus urogenitalis. They are minute epithelial buds developing from the ventral wall of the sinus (Fig. 32).

\subsection{Gl. praeputiales}

In embryos about $25 \mathrm{~mm}$ long besides the mentioned above buds of the accessory glands one observes also the paired buds of the gl. praeputiales. They are situated on both sides of the penile urethra, lying between the balano-praeputial fold and the epithelium covering the tuberculum genitale. They are alveolo-tubular glands, of the sebaceous type (Fig. 31). Their ducts are emptying outside on both sides of the opening of the urogenital canal.

\section{DISCUSSION}

In view of the obtained results it should be noticed that both the structure and development of male accessory genital glands in Apode- 
mus agrarius are, as it was expected, similar to those observed in rat and mouse. There is, moreover, a close resemblance in the structure of genital tracts between the mentioned above representatives of Muridae and the representatives of Microtidae (e.g. Microtus and Clethrionomys). In all mentioned above genera occur the same types of accessory glands whose localization is identical and development is very similar. Significant differences if they exist at all, are most probably of physiological nature. This will be demonstrated on prostatic glands taken as an example.

The differentiation of prostatic glands into three groups: dorsal, lateral and ventral ones, has been observed in all mentioned genera, their microscopic structure, however, is not always identical. In the representatives of the genera Microtus and Clethrionomys lateral and ventral lobes of the prostate have similar structure (R a y n u d, 1951, D e lost, 1955; In dy k, 1968) the only differences being observed in the size of tubes and height of their epithelium. Therefore it may be spoken about the ventro-lateral prostate. Dorsal prostate has a different structure being similar to that of the coagulating glands. In Rattus one distinguishes the dorso-lateral and ventral groups of the prostate. This differentiation is confirmed by microscopic structure of those groups as well as by biochemical data ( $\mathrm{M}$ a $\mathrm{n} n, 1964)$. The ventral prostate has a distinctly different structure and contains citric acid and alkaline phosphatase. It does not contain fructose. The dorso-lateral prostate of the rat, as a whole, does contains fructose. In the dorso-lateral prostate itself it is possible, however, to distinguish three smaller regions, the »dorsal " portion and two »lateral « lobes, whose secretion differ by their chemical properies. The studies on the prostatic gland in Mus musculus suggest that their differentiation is analogical to that stated in rat ( $\mathrm{M}$ a $\mathrm{n} n$, l.c.). Although no histochemical method have been applied in the present investigations, it seems, however, that the structure of the prostatic glands in A. agrarius is similar to that in Rattus. Dorsal and lateral prostatic glands show only slight differences in their microscopic structure and are not separated from each other, whereas the microscopic structure of the ventral prostate is remarkably different. A strong affinity of the cytoplasm of its cells to hematoxylin (basophilicity) suggest its resemblance with the ventral prostate of the rat in which »the cytoplasm of the epithelial cells is strongly basophilic owing to the presence of secretory granules which are laden with ribonucleic acid « ( $\mathrm{M}$ a n n, 1964). So far no biochemical investigations on prostatic glands in Microtinae are known. It seems, however, possible that separate groups of the prostatic glands in Microtidae and Muridae are physiologically not homologous. 
Differences in the number of ducts and buds of separate groups of the prostate appearing between the species are not significant, since it is not possible to establish the exact number of efferent ducts in each of the described groups of the prostate. The data taken from developing embryos and adult individuals of $A$. agrarius show a great individual variability in this respect.

Only in case of coagulating glands the matter is relatively simple. In A. agrarius they always develop from one pair of buds and in adult individual they open to the urethra throughout one pair of ducts. Similar description is given by $\mathrm{M}$ a $\mathrm{n} n$ (l.c.) for rat, mouse and guinea pig, and by In dy k (l.c.) for Pitymys, Clethrionomys and Microtus. In the last three genera A rata (1964) has stated two efferent ducts on each side. The ducts of coagulating glands in Apodemus are easily determined since those glands differ distinctly from the dorsal prostate, while in Microtinae both glands have similar structure (Indyk, l.c.) and it is easy to take a duct of the dorsal prostate for the duct of the coagulating gland.

The structure of the vesiculae seminales and gl. ampullarum in A. agrarius is analogical to that in other species of Rodentia. The above glands showing a high stability in shape and structure are practically of no taxonomical value ( $\mathrm{Kr}$ a tochvil, 1960; Arata, 1964).

The bulbo-urethral glands have a uniform structure and development in almost all mammals. Nevertheless, more detailed studies may detect some differences among particular species. In $A$. agrarius the ducts of those glands are relatively short, like in rat $(\mathrm{Stuzmann}, 1899-$ quoted after Szarski, 1935) whereas in other mammals they are as a rule long. In walls of the ducts one observes a thick layer of urethral glands with agglomerations of glandular tissue identical to the tissue of the substance of the bulbo-urethral glands. The duct in thus practically the extension of the gland and performes also a secretory role. Glandular character of the ducts of the bulbo-urethral glands in various mammals is generally known (cf. Kowalska-D y r cz, 1966). The data are, however, not exact. Most frequently it is not clear whether this glandular character is to be ascribed to the urethral glands accompanying the ducts or to the agglomeration of tissue identical with the tissue of the bulbo-urethral glands. E.g. in shrews (in which the urethral glands are absent) one observes on the ducts only minute bulbo-urethral glands (K ow a lska-D y r cz, 1966).

The presence of double buds of the bulbo-urethral glands on either side in A. agrarius should be emphasized. The second, additional pair of those buds appears in embryos $25 \mathrm{~mm}$ long, thus at the moment where the pair of main buds is definitely formed (differentiated into the sub- 
stance of the gland and the duct). Since the bulbo-urethral glands in adult males have only one pair of ducts, it should be supposed that either further development of this additional pair is arrested, or that this pair gives rise to one of small glands accompanying the efferent ducts of those glands. The presence of double buds of the bulbo-urethral glands has been mentioned by $\mathrm{Sz}$ a r s ki (1935) in Mus musculus.

\section{REFERENCES}

1. Arat a R., 1964: The anatomy and taxonomic significance of the male accessory reproductive glands of muroid rodents. Bull. Florida State Mus., 9, 1: 1-42.

2. Delost P., 1955: Anatomie et structure histologique de l'appareil génital du Campagnol des champs (Microtus arvalis, $\mathrm{P}$ a $11 \mathrm{as}$ ) adulte en activité sexuelle. Bull. Soc. Zool. France, 80: 207-222.

3. In dy k F.; 1968: The structure of the prostatic part of the urethra and of its glands in some Microtinae. Acta theriol., 13, 14: 261-276.

4. Kowalska-Dy r cz A., 1966: A comparative study of the male genital tract in some species of shrews. Acta theriol., 11, 4: 71-127.

5. Kratochvíl J., 1960: Sexualdrüsen bei den Saügetieren mit Rücksicht auf Taxonomie. Symp. theriol., 175-187. Czechoslov. Acad. Sci., Brno.

6. Mann T., 1964: The biochemistry of semen and of the male reproductive tracts. Methuen \& Co Ltd. John Wiley \& Sons Inc.: 1-493. London - New York.

7. $\mathrm{R}$ a u the r M., 1904: Uber den Genitalapparat einiger Nager und Insectivoren, insbesondere die akzessorischen Genitaldrüsen derselben. Jena. Z. Naturw., 38: 377-472. Jena.

8. R a y $\mathrm{n}$ a u d A., 1942: Recherches embriologiques et histologiques sur la différentiation sexuelle normale de la Souris. Bull. Biol. Suppl., 29: 1-144. Paris.

9. R a y $\mathrm{n}$ a u d A., 1951: Les glandes annexes du tractus urogénital des Campagnols agrestes (Microtus agrestis L.). Bull. Biol., 85: 323-372.

10. Rietschel P. F., 1929: Zur Morphologie und Histologie der Genitalausführungsgänge in Individual-zyklus der weissen Maus. Z. wiss. Zool., 135: 428-493. Leipzig.

11. Szarski K. W., 1935: Przyczynek do badań nad rozwojem i budową gruczołów dodatkowych (Gll. accessoriae) dróg moczo-płciowych myszy białej. Archiwum Tow. Nauk. we Lwowie, 6: 1-142.

Received, July 27, 1969.

Department of Comparative Anatomy,

Wrocław University,

Wrocław, Sienkiewicza 21. 


\section{Alina KOWALSKA-DYRCZ i Aurelia PAWŁOWSKA-INDYK \\ BUDOWA I ROZWOJ MĘSKICH DODATKOWYCH GRUCZOEÓW PŁCIOWYCH U MYSZY POLNEJ}

\section{Streszczenie}

Opisano budowę i rozwój męskich dodatkowych gruczolów płciowych Apodemus agrarius (P a 1las, 1771), w oparciu o analizę mikroskopową układu płciowego 5 dojrzałych samców i 26 zarodków ơ w czterech różnych stadiach rozwoju.

Stwierdzono, że prócz dodatkowych gruezołów płciowych takich jak: gl. ampullarum, ampulla, vesiculae seminales, gl. coagulantes, gl. prostaticae, gl. bulbo-urethrales i gl. urethrales, również nabłonki cauda epididymidis i vas deferens przejawiają funkcję wydzielniczą.

W obrębie cauda epididymidis można wyróżnić dwa obszary, oddzielone od siebie pasmami mięśni gladkich: jeden utworzony $z$ przewodu najądrza i drugi utworzony $\mathrm{z}$ vas deferens. Nabłonek przewodów w obu częściach najądrza jest podobny i czynny wydzielniczo. Szczególnie intensywną sekrecję wykazuje nabłonek dystalnej części nasieniowodu.

Vas deferens i vesiculae seminales lączą się z każdej strony w krótki ductus ejaculatorius lub uchodzą niezależnie do uretry. Istnieje duża zmienność indywidualna pod tym względem. W każdym jednak przypadku przewody te uchodzą do grzbietowych, parzystych kieszeni w obrębie colliculus seminalis.

Stwierdzono podział gruczołów prostaty na 3 grupy: grzbietową, boczne i brzuszną. G. prostaticae dorsales et laterales wykazują niewielkie różnice w budowie mikroskopowej i nie sa od siebie odgraniczone. Prostata brzuszna jest natomiast wyraźnie wyodrębniona pod względem budowy mikroskopowej. Istnieje duża zmienność indywidualna w ilości przewodów wyprowadzających poszczególnych grup prostaty, jak też w ilości zawiązków danej grupy prostata u zarodków z tego samego miotu.

Gl. coagulantes rozwijają się zawsze z jednej pary zawiązków a u dorosłych uchodzą parą przewodów wyprowadzających do uretry. Ich budowa jest wyraźnie różna od budowy prostata dorsalis.

Budowa vesiculae seminales i gl. ampullarum jest zupelnie podobna do tej $\mathrm{u}$ innych gatunków Muridae. Również gl. bulbo-urethrales nie odbiegają w budowie i rozwoju od tych gruczołów u innych badanych ssaków. Na uwagę zasługuje jedynie fakt występowania u niektórych zarodków podwójnych zawiązków tych gruczołów z każdej strony.

Gl. urethrales występują $\mathrm{w}$ pars membranacea urethrae $\mathrm{w}$ stosunkowo małej ilości, skupione głównie po stronie brzusznej. Duże skupienia tych gruczołów spotyka się jedynie w ścianach sinus urethrae bulbi i przewodów wyprowadzających gruczołów opuszkowo-cewkowych.

U dorosłych samców nie stwierdzono żadnych śladów przewodów Müllera. 


\section{EXPLANATION OF PLATES}

\section{Plate XVIII.}

Fig. 1. Urogenital system, ventral side $-\sigma^{\top}$ ad.

Fig. 2. Urogenital system, dorsal side $-\sigma^{7}$ ad., magn. as in Fig. 1.

Fig. 3. Cross-section through the distal portion of the cauda epididymidis.

Fig. 4. Cross-section through the distal portion of the vas deferens.

Fig. 5. A fragment of the cross-section through the urogenital complex made on the level with the ampullae vasorum deferentium.

Fig. 6. A fragment of the seminal vesicles epithelium.

Fig. 7. A fragment of the cross-section through the vas deferens (cf. Fig. 4).

Fig. 8. A fragment of the epithelium of gl. ampullarum. Magn. as in Fig. 12.

Fig. 9. A fragment of the epithelium of the lateral prostate. Magn. as in Fig. 6.

Fig. 10. A fragment of the epithelium of the dorsal prostate.

Fig. 11. A fragment of the epithelium of the coagulating glands. Magn. as in Fig. 6.

Plate XIX.

Fig. 12. A fragment of tubes of the lateral prostate (on the left) and of the ventral prostate (on the right).

Fig. 13. A fragment of the epithelium of the ventral prostate. Magn. as in Fig. 7 .

Fig. 14. Cross-section through the urethra, on a level with the crista urethralis. Magn, as in Fig. 15.

Fig. 15. Cross-section through the colliculus seminalis on a level with the openings of the vasa deferentia.

Fig. 16. Longitudinal section through the sinus urethrae bulbi.

Fig. 17. Longitudinal section through a fragment of the gl. bulbo-urethralis duct, cut tangentially. The lumen of the duct is marked by an arrow.

Fig. 18. Cross-section through the pars membranacea urethrae.

Fig. 19. A fragment of the tissue of bulbo-urethral glands. Magn. as in Fig. 6.

\section{Plate XX.}

Fig. 20. Cross-section through the sinus urogenitalis in embryo $11 \mathrm{~mm}$ long. Made on the level with the openings of the Wolffian ducts.

Fig. 21. Cross-section through the same embryo (cf. Fig. 20) made somewhat more caudally. Magn. as in Fig. 20.

Fig. 22. Cross-section through the sinus urogenitalis in embryo $18 \mathrm{~mm}$ long on the level with the buds of coagulating glands.

Fig. 23. Cross-section through the funiculus genitalis in embryo $25 \mathrm{~mm}$ long. Magn. as in Fig. 24.

Fig. 24. Cross-section through the same embryo as in Fig. 20 and 21 , made on the level with the buds of the bulbo-urethral glands. (The bud is marked by an arrow).

Fig. 25. Cross-section through the funiculus genitalis in the same embryo as in Fig. 23, made somewhat more cranially. Magn. as in Fig. 24.

Fig. 26. Cross-section through the sinus urogenitalis in embryo $25 \mathrm{~mm}$ long, made the level with the ejaculatory ducts.

Fig. 27. Cross-section through the sinus urogenitalis in embryo $25 \mathrm{~mm}$ long, made the level with the buds of coagulating glands. Magn. as in Fig. 26.

Fig. 28. Cross-section through the sinus urogenitalis in embryo $25 \mathrm{~mm}$ long, made the level with the buds of dorsal prostate. Magn, as in Fig. 30. 
Plate XXI.

Fig. 29. Cross-section through the sinus urogenitalis in embryo $26 \mathrm{~mm}$ long, made the level with the buds of ventral prostate. Magn. as in Fig. 24.

Fig. 30. Cross-section through the sinus urogenitalis in embryo $26 \mathrm{~mm}$ long, made the level with the utriculus prostaticus.

Fig. 31. Cross-section through the embryo $25 \mathrm{~mm}$ long, made the level with the tuberculum genitale. The buds of gl. praeputiales cut longitudinally.

Fig. 32. Cross-section through the pars pelvina sinus urogenitalis in embryo $25 \mathrm{~mm}$ long. The buds of the urethral glands marked by arrows.

Fig. 33. Cross-section through the sinus urogenitalis in embryo $25 \mathrm{~mm}$ long, made the level with the buds of the bulbo-urethral glands.

Fig. 34. Cross-section through the distal portion of buds of the bulbo-urethral glands in embryo $25 \mathrm{~mm}$ long. The arrow points dorsal direction.

\section{ABBREVIATIONS}

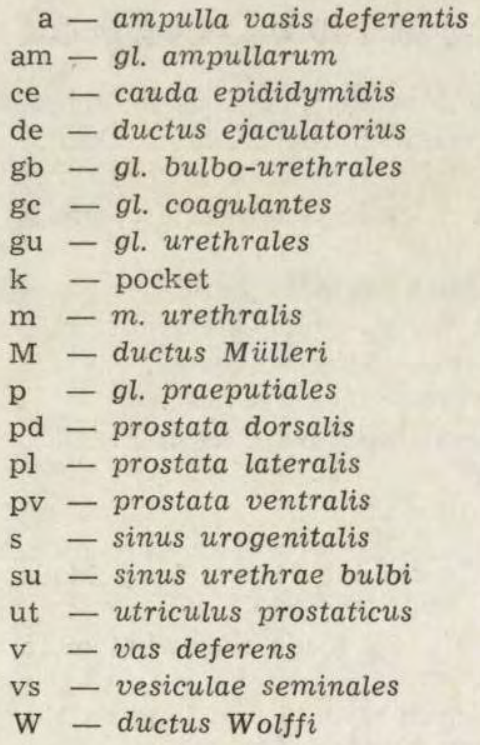




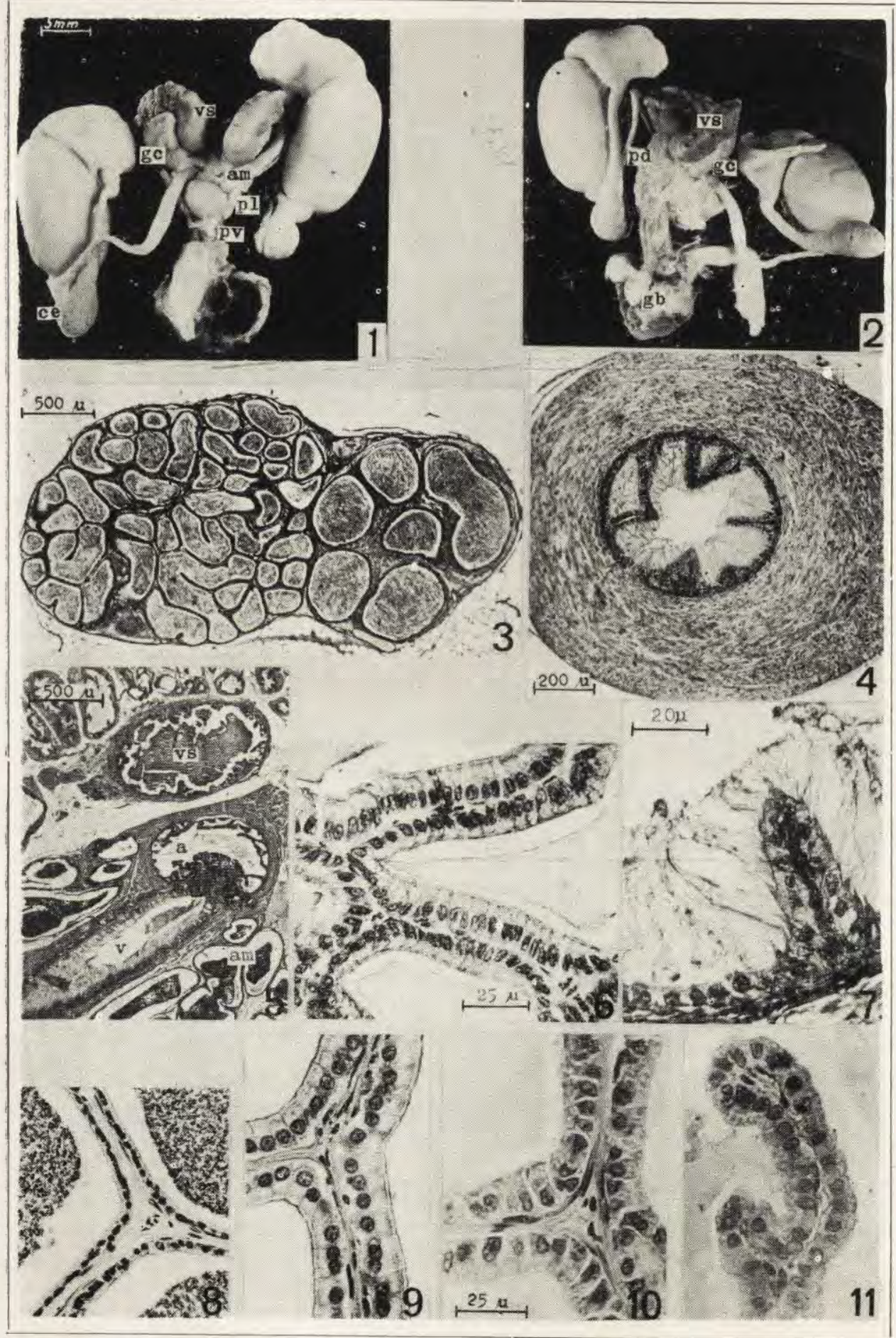

A. Kowalska-Dyrcz \& A. Pawlowska-Indyk auctores phot. 


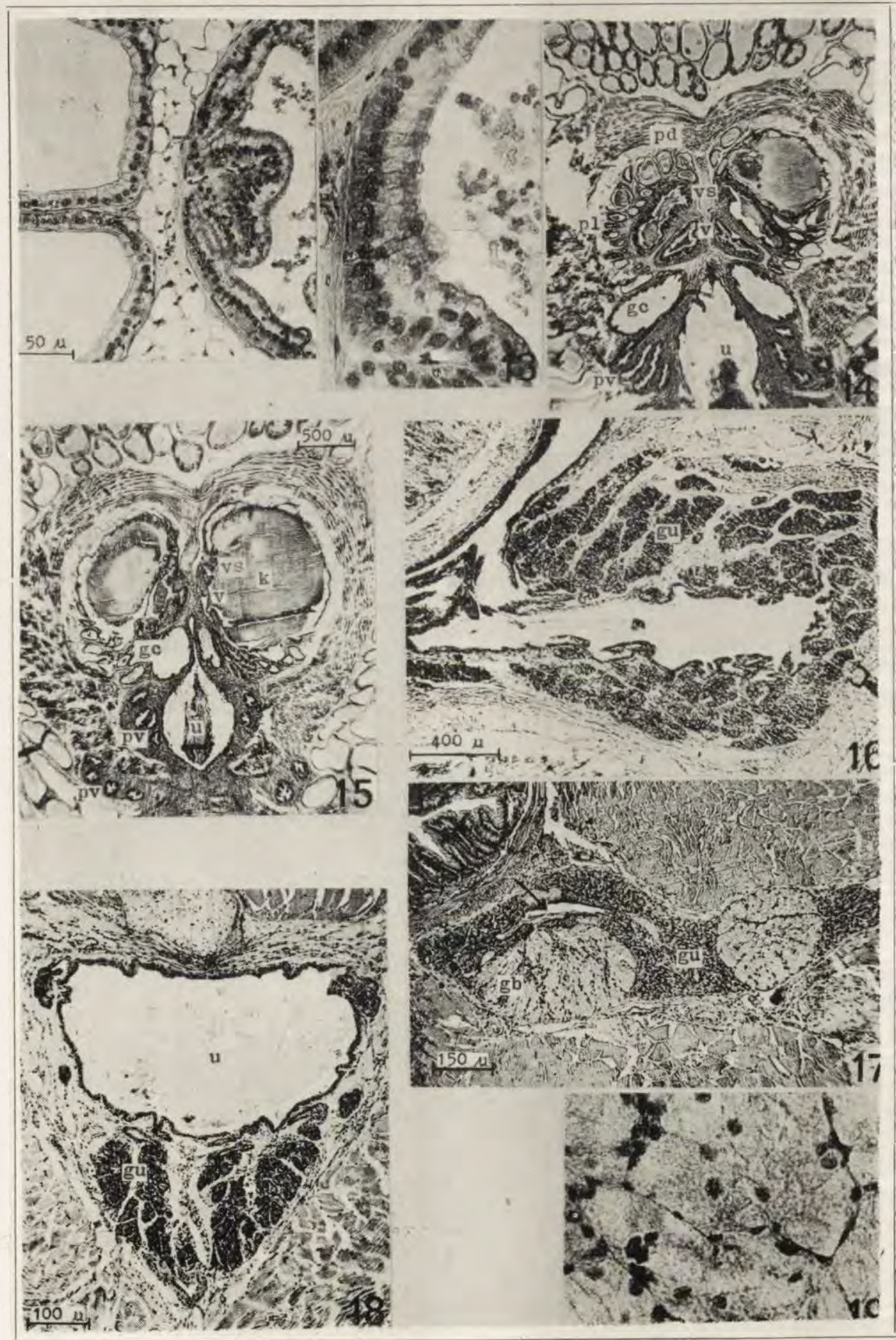

A. Kowalska-Dyrcz \& A. Pawłowska-Indyk 

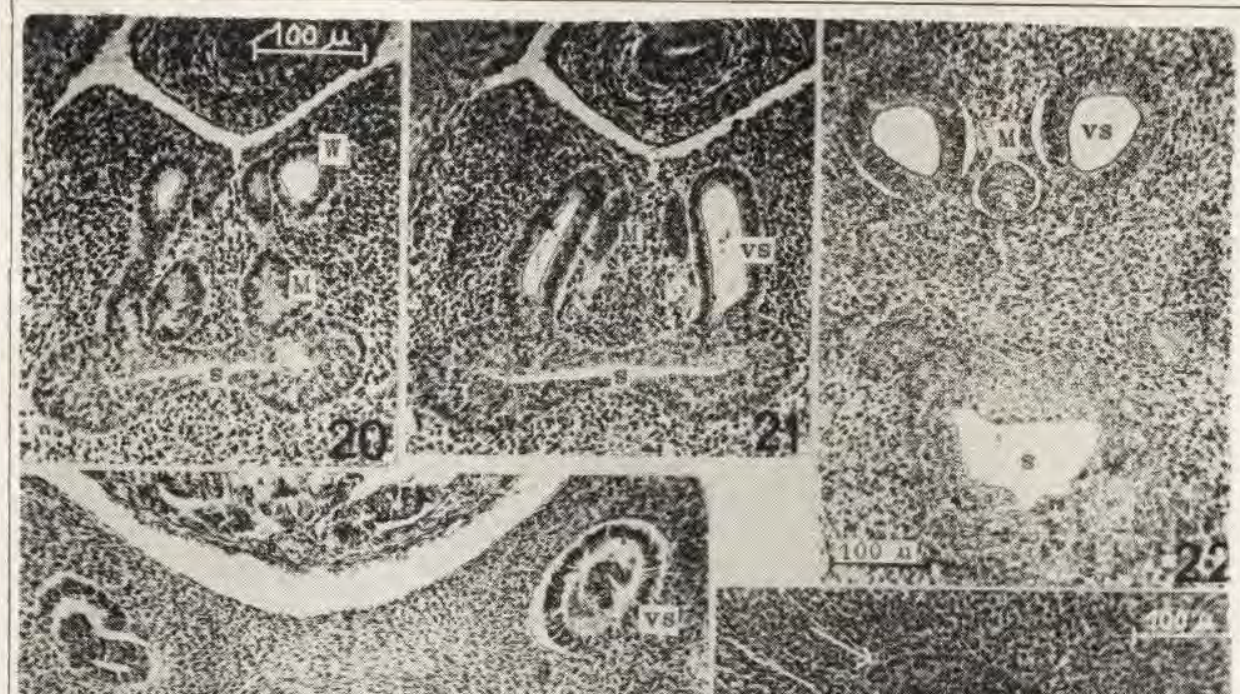

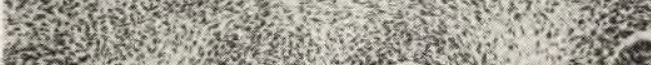

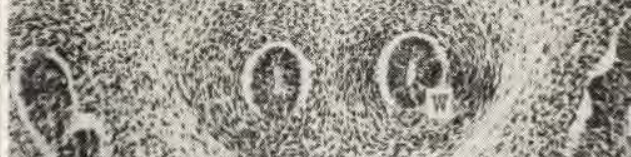

1. 12 .

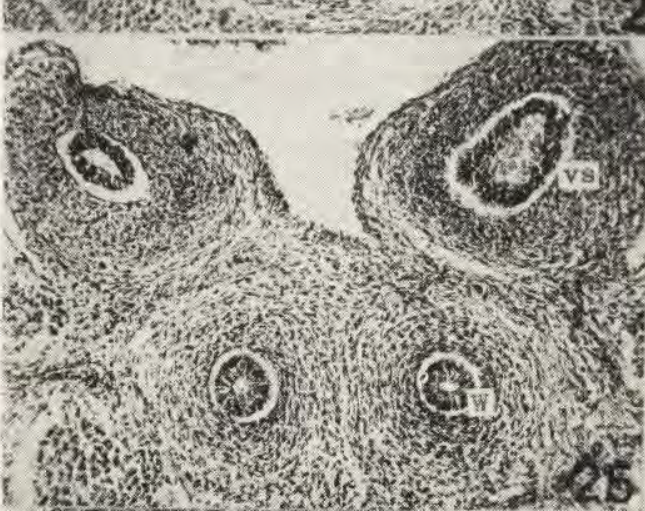

1 3.

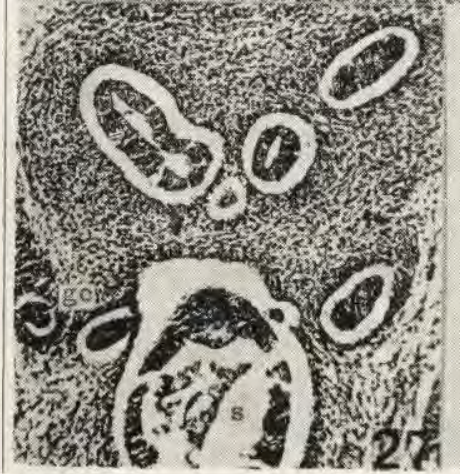

की
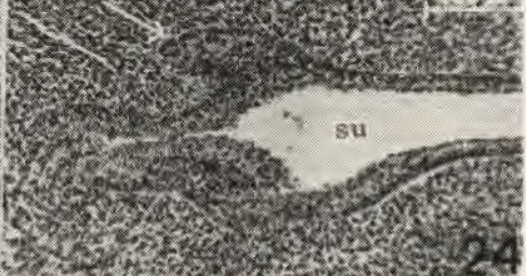

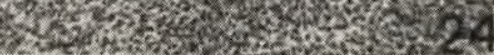
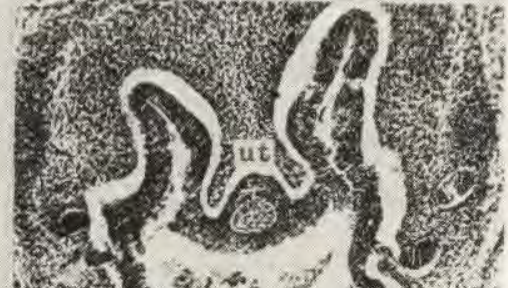

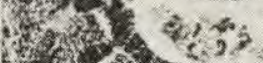
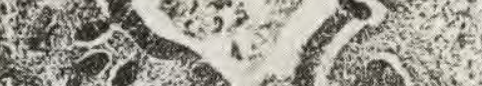

Thorom

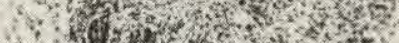

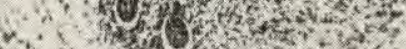

in 26

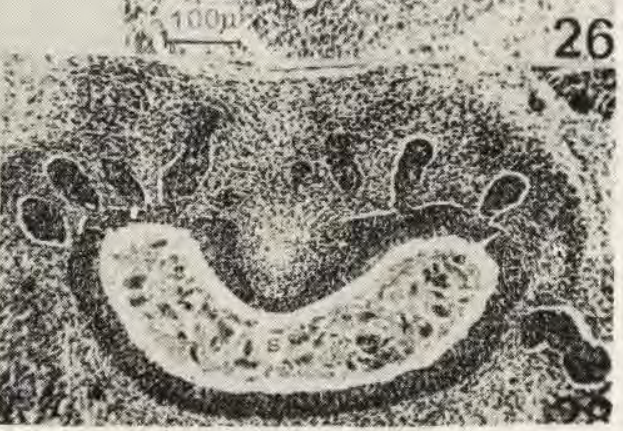

A. Kowalska-Dyrez \& A. Pawłowska-Indyk

auctores phot. 
ACTA THERIOLOGICA, Vol. XIV, 32.

Plate XXI.

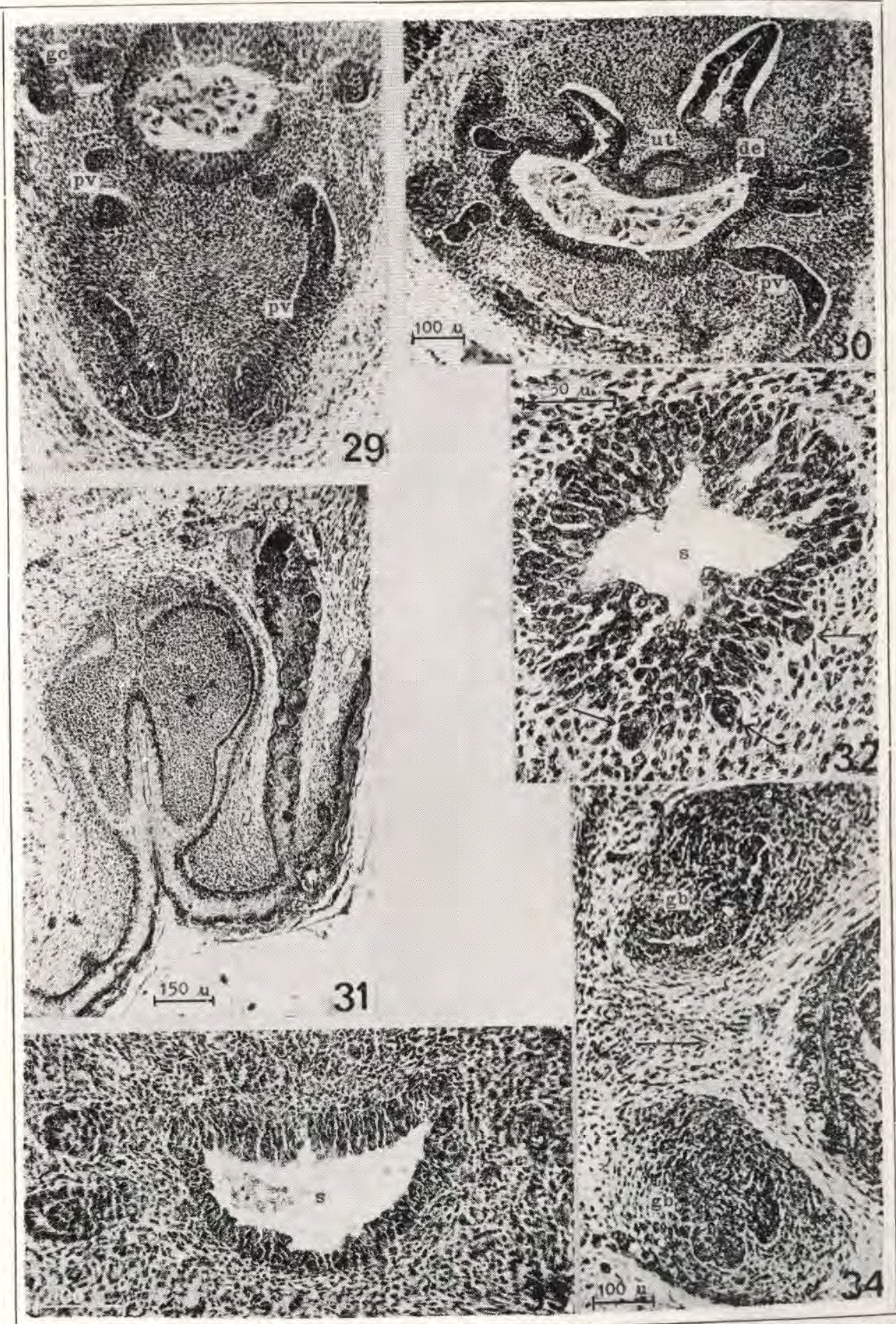

A. Kowalska-Dyrcz \& A. Pawłowska-Indyk 